\title{
Original
}

\section{Antitumor Effect of the Combination of CGS16949A and 5-FU against Human Breast Cancer Cell Lines}

\author{
Rang Zhang, Yuko Tsunoda, Kentaroh Kamiya, \\ Miki Shibusawa, Mitsuo Kusano, Yukiko Shimizu*, \\ Yoshiro Toma* and Takumi YanaIHARA*
}

\begin{abstract}
The aim of this study was to evaluate the combined antitumor effect of CGS16949A and 5-fluorouracil (5-FU) against human breast cancer cell lines. MCF-7, SK-BR-3, and MDA-MB-231 were cultured and measured with $\left[{ }^{3} \mathbf{H}\right]$ water assay and MTT assay. Three human breast cancer cell lines were treated with $10 \mathrm{nM}$ CGS16949A and $100 \mu \mathrm{g} / \mathrm{ml}$ 5-FU. The aromatase activities (percent aromatase activity) of the three human breast cancer cell lines were significantly inhibited by CGS16949A. In particular, combined treatment with CGS16949A and 5-FU inhibited aromatase activities more than did CGS16949A alone. In two cell lines (SK-BR-3 and MDA-MB-231) inhibition rates increased with 5-FU in a dose-dependent manner, and, in particular, the combined antitumor effect of CGS16949A and 5-FU against SK-BR-3 with the MTT assay was shown. To our knowledge, this is the first report of a combined antitumor effect of an aromatase inhibitor (CGS16949A) and 5-FU in three human breast cancer cell lines.
\end{abstract}

Key words : breast cancer, cell lines, aromatase, CGS16949A, fluorouracil

\section{Introduction}

Aromatization of breast carcinoma has been found to occur to a greater degree in postmenopausal women, in whom the most important source of estrogens, the ovary, is absent $^{1,2)}$. Aromatase is present in human breast tumors and in breast cancer cell lines, a finding that suggests the possibility of in-situ estrogen production via androstenedione to estrogen $^{3)}$. CGS16949A (Fadrozole, Novartis, Basel, Seitzerland) is a nonsteroidal competitive inhibitor of aromatase and plays an important role in the blocking of estrogen synthesis ${ }^{4}$. In postmenopausal women, aromatase inhibitors are reported to be useful for the treatment of breast cancer $^{5,6)}$. 5-fluorouracil has been widely used in the adjuvant chemotherapy for women with advanced breast cancer with or without estrogen receptors. The antitumor effect of CGS16949A or 5-FU has been investigated ${ }^{7-10)}$; however, the effect of the combination CGS16949A and 5-FU has not been reported. The purpose of this study was to investigate the antitumor effect of the combination of CGS16949A and 5-FU against three human breast cancer cell lines in vitro.

Second Department of Surgery, Showa University School of Medicine, 1-5-8 Hatanodai, Shinagawa-ku, Tokyo 1428666, Japan.

* Department of Obstetrics and Gynecology, Showa University School of Medicine. 


\section{Materials and Methods}

\section{Cell lines}

The human breast cancer cell lines MCF-7, SK-BR-3, and MDA-MB-231 were purchased from the American Type Culture Collection (Rockville, MD, USA). The three cell lines were grown in $25-\mathrm{cm}^{2}$ tissue culture flasks, but the culture media and cell culture conditions were different. MCF-7 was grown in Eagle's minimum essential medium (Nissui Pharmaceutical Co., Ltd., Tokyo, Japan) with nonessential, nonacidic, phenol red, and $10 \%$ fetal calf serum (FCS) plus $1 \mathrm{mM}$ sodium pyruvate (Gibco BRL, Grand Island, NY, USA) and $10 \mu \mathrm{g} / \mathrm{ml}$ bovine insulin (Gibco BRL). SK-BR-3 was grown in McCoy's 5 a medium (Gibco BRL) containing $10 \%$ FCS. MDA-MB-231 was grown in Leibovitz's L-15 medium (Gibco BRL) with $10 \%$ FCS. MCF-7 and SK-BR-3 were incubated at $37{ }^{\circ} \mathrm{C}$ in air with $5 \% \mathrm{CO}_{2}$. MDA-MB-231 was incubated at $37^{\circ} \mathrm{C}$ in a closed system without $\mathrm{CO}_{2}$. The media of all cell cultures were changed every 3rd day. Estrogen receptors have been reported in MCF-7 and SK-BR-3 but not in MDA-MB-231.

Chemicals

CGS16949A was provided by Novartis. 5-FU was purchased from the Kyowa Hakko Co., Ltd (Tokyo, Japan) in an injectable form. $\left[1 \beta_{-}{ }^{3} \mathrm{H}\right]$ Androstenedione $(24.70 \mathrm{Ci} / \mathrm{mmol})$ was purchased from New England Nuclear Corp. (Boston, MA, USA). MTT (3-[4,5dimethylthiazol-2-yl]-2,5-diphenyl tetrazolium bromide) was purchased from Sigma Chemical Co. (St. Louis, MO, USA).

Aromatase activity assay

Aromatase activity in the three cell lines was measured with the tritiated water method as previously described ${ }^{11,12)}$. Briefly, cells were seeded in duplicate at a density of $1 \times 10^{5}$ cells/dish in $5 \mathrm{ml}$ feeding medium in $60-\mathrm{mm}$ Petri dishes. The cells were grown for 1 week until confluent in medium. Preconfluent cells were incubated with $\left[\begin{array}{lll}1 & \beta & -3 \\ -\end{array}\right]$ androstenedione as a substrate to a concentration of $100 \mathrm{nM}$ at $37{ }^{\circ} \mathrm{C}$ in air with $5 \% \mathrm{CO}_{2}$ for 5 hours. After incubation for 5 hours, $1.5 \mathrm{ml}$ of culture medium was transferred to a test tube, to which $0.2 \mathrm{ml}$ of $30 \%$ trichloroacetic acid and $0.5 \mathrm{ml}$ of $10 \%$ charcoal were added and mixed. The mixture was incubated at $37{ }^{\circ} \mathrm{C}$ in air for 30 minutes. The mixture was centrifuged, and the supernatant was filtered through a cotton-plugged Pasteur pipette. The amount of $\left[{ }^{3} \mathbf{H}\right]$ water in the eluate was assessed on the basis of the theory that $[1 \beta-$ $\left.{ }^{3} \mathbf{H}\right]$ is eliminated during aromatization of the $\left[1 \beta-{ }^{3} \mathbf{H}\right]$ androstenedione substrate $(75 \%$ release into water). The $\left[{ }^{3} \mathrm{H}\right]$ radioactivity in medium was measured with a liquid scintillation counter (Aloka LSC-651, Tokyo, Japan). Ten nanomoles of CGS16949A alone, $100 \mu \mathrm{g} / \mathrm{ml}$ of $5-\mathrm{FU}$ alone, or a combination of CGS16949A and 5-FU were added to investigate their inhibitory effects on enzymatic activities. Protein content was measured with the protein-dye binding method (Tonein-TP, Ozuka, Japan) ${ }^{13}$.

Chemosensitivity test (MTT assay)

MTT was measured with 3-[4,5-dimethylthiazol-2-yl]-2,5-diphenyl tetrazolium bromide, succinic acid, and dimethyl sulfoxide (DMSO). Subconfluent cultures of breast cancer cell lines were trypsinised and washed twice with the medium. Single cell suspensions with 20 $\%$ FCS were seeded at a density of $1 \times 10^{4}$ cells/well in $50 \mu 1$ nutrient medium with or without phenol red in 96-well plates. In cultures treated with CGS16949A alone, predetermined concentrations (10 and $100 \mathrm{nM}$ ) of CGS16949A dissolved in ethanol were dried, then diluted with the medium with or without phenol red. In cultures treated with 
CGS16949A and 5-FU, CGS16949A (10 nM) dissolved in ethanol was dried, then diluted with 5-FU, including predetermined medium concentrations for 10,100 , and $1000 \mu \mathrm{g} / \mathrm{ml}$. In cultures treated with 5 -FU alone, predetermined concentrations $(10,100$, and $1000 \mu \mathrm{g} / \mathrm{ml})$ of 5-FU were diluted directly with the culture medium. Then the medium was added at $50 \mu \mathrm{g} /$ well in quadruplicate to achieve a total volume of $100 \mu \mathrm{g} /$ well. After incubation for 72 hours as above, $10 \mu 1$ of MTT and succinic acid were added to each well. The plates were incubated for 3 hours, and $200 \mu 1100 \%$ dimethyl sulforide was added to each well.

The plates were read at an absorbance of $560 \mathrm{nM}$ on a MTP-120 microplate reader (Corona Electric Co., Ltd., Ibaragi, Japan). The inhibition rate was calculated according to the equation : inhibition rate $=[(\mathrm{a}-\mathrm{p}) /(\mathrm{a}-\mathrm{m})] \times 100(\%)$

a : control absorbance units

$\mathrm{m}$ : background absorbance units

$\mathrm{p}$ : treatment absorbance units

Statistical analysis

Fisher's protected least significant difference (PLSD) test was used to examine the statistical significance of change in inhibition rates, which are expressed as the mean \pm sta ndard deviation (SD).

\section{Results}

\section{Aromatase activity assay}

The aromatase activities of MCF-7, SK-BR-3, and MDA-MB-231 without putative inhibitors were 106, 3250, and $132 \mathrm{fmol} /$ hour $/ \mathrm{mg}$ protein, respectively. The aromatase activity of MCF-7 was inhibited $26 \%, 63 \%$, and $22 \%$ in the presence of $10 \mathrm{nM}$ CGS16949A, $100 \mu \mathrm{g} / \mathrm{ml}$ 5-FU,and a combination of CGS16949A and 5-FU, respectively. The aromatase activity of SK-BR-3 cells was inhibited $15 \%, 73 \%$, and $11 \%$ in the presence of $10 \mathrm{nM}$ CGS16949A, $100 \mu \mathrm{g} / \mathrm{ml} \mathrm{5-FU,} \mathrm{and} \mathrm{a} \mathrm{combination} \mathrm{of} \mathrm{CGS16949A} \mathrm{and}$ 5-FU, respectively. The aromatase activity of MDA-MB-231 cells was inhibited $58 \%, 78$ $\%$, and $63 \%$ in the presence of $10 \mathrm{nM} \mathrm{CGS16949A,} 100 \mu \mathrm{g} / \mathrm{ml} \mathrm{5-FU}$, and a combination of CGS16949A and 5-FU, respectively (Fig. 1).

MTT assay

For the MCF-7 cell line, the inhibition rate with 10 and $100 \mathrm{nM}$ CGS16949A was estimated at $10.2 \%$ and $12.8 \%$. The inhibition rate was less than $50 \%$ even with 1000 $\mu \mathrm{g} / \mathrm{ml} \mathrm{5-FU} \mathrm{alone.} \mathrm{The} \mathrm{inhibition} \mathrm{rate} \mathrm{was} \mathrm{estimated} \mathrm{to} \mathrm{be} \mathrm{greater} \mathrm{than} 50 \%$ only when both $1000 \mathrm{~g} / \mathrm{ml} \mathrm{5-FU}$ and $10 \mathrm{nM}$ CGS16949A were administered. For the SK-BR-3 cell line, the inhibition rate with 10 and $100 \mathrm{nM}$ CGS16949A was estimated at $35.8 \%$ and 29.5 $\%$. The sensitivity of SK-BR-3 to CGS16949A was higher than that of MCF-7. The inhibition rate with 5-FU alone increased in a dose-dependent manner and reached $48 \%$ with $100 \mu \mathrm{g} / \mathrm{ml} \mathrm{5-FU.} \mathrm{The} \mathrm{inhibition} \mathrm{rate} \mathrm{with} 10 \mathrm{nM} \mathrm{CGS16949A}$ and $100 \mu \mathrm{g} / \mathrm{ml} 5$-FU was $60 \%$, similar to that with $1000 \mu \mathrm{g} / \mathrm{ml} \mathrm{5-FU} \mathrm{alone.} \mathrm{For} \mathrm{the} \mathrm{MDA-MB-231} \mathrm{cell} \mathrm{line,}$ the inhibition rate with 10 or $100 \mathrm{nM}$ CGS16949A was approximately $15 \%$ and similar to that for MCF-7 cells. However, for the MDA-MB-231 cell line, the inhibition rate with 5-FU increased in a dose-dependent manner and was $29 \%$ with $100 \mu \mathrm{g} / \mathrm{ml}$ 5-FU. In contrast, the combination of $10 \mathrm{nM} \mathrm{CGS16949A}$ and $100 \mu \mathrm{g} / \mathrm{ml} \mathrm{5-FU} \mathrm{did} \mathrm{not} \mathrm{effectively}$ inhibit the MDA-MB-231 cell line (Fig. 2).

The inhibition rates of the three human breast cancer cell lines are shown in Fig. 3 . 


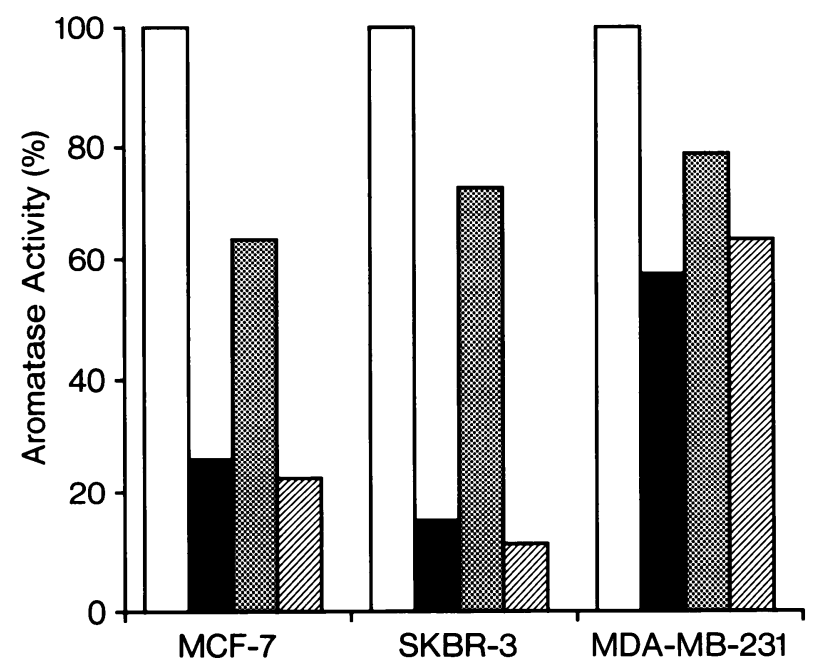

Fig. 1. The effect of aromatase inhibitor CGS16949A and 5-FU on aromatase activity in human breast cancer cell lines as measured with the $\left[{ }^{3} \mathbf{H}\right]$ water release method.

$\square$, Control ; $\square$, CGS16949A (10 nM); 5-FU $(100 \mu \mathrm{g} / \mathrm{ml})$; and $\dddot{W}$, CGS16949A $(10 \mathrm{nM})$ and 5-FU $(100 \mu \mathrm{g} / \mathrm{ml})$.

For the MCF-7 and SK-BR-3 cell lines, the inhibition rates were significantly higher with $10 \mathrm{nM}$ CGS16949A and $100 \mu \mathrm{g} / \mathrm{ml}$ 5-FU than with $10 \mathrm{nM}$ CGS16949A alone. The combination of CGS16949A and 5-FU produced inhibition rates of more than $50 \%$ and was the only treatment to have an antitumor effect against the SK-BR-3 cell line.

\section{Discussion}

While the antitumor effect of the aromatase inhibitor CGS16949A on human breast cancer cell lines and the antitumor effect of 5-FU against breast cancer cell lines have been reported $^{14-16)}$, the effect of the combination of CGS16949A and 5-FU on human breast cancer cells has not yet been reported. In this study, we investigated the antitumor effect of CGS16949A or 5-FU alone and the combined antitumor effect of CGS16949A and 5-FU against human breast cancer cell lines with $\left[{ }^{3} \mathbf{H}\right]$ water assay and MTT assay.

CGS16949A is a nonsteroidal competitive inhibitor of aromatase ${ }^{4)}$. Yano et al. ${ }^{14)}$ reported that the aromatase activity of MCF-7 is inhibited by CGS16949A in a dose-dependent manner,which suggests that one of the growth-inhibiting mechanisms of CGS16949A is the inhibition of intracellular aromatase activity. In our study, the aromatase activity of three

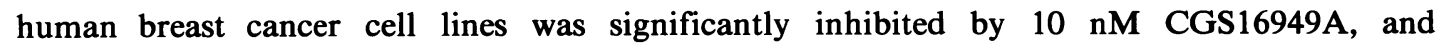
inhibited to a lesser extent by $100 \mu \mathrm{g} / \mathrm{ml} \mathrm{5-FU.} \mathrm{The} \mathrm{aromatase} \mathrm{activity} \mathrm{of} \mathrm{these} \mathrm{cells} \mathrm{was}$ inhibited more effectively by a combination of $10 \mathrm{nM}$ CGS16949A and $100 \mu \mathrm{g} / \mathrm{ml} 5$-FU than by each agent alone. Dowsett et al. ${ }^{15)}$ reported that cytotoxic chemotherapy suppresses aromatase activity in breast carcinomas in vivo. Cytotoxic chemotherapy might preferentially lead to the death of aromatase-positive cells. MTT assay in the present study showed that the inhibition rates of 5-FU increased in a dose-dependent manner in SK-BR-3 and MDA-MB-231. The combination of $10 \mathrm{nM} \mathrm{CGS16949A}$ and $100 \mu \mathrm{g} / \mathrm{ml} \mathrm{5-FU} \mathrm{had} \mathrm{an}$ antitumor effect against SK-BR-3 which was as great as that with $1000 \mu \mathrm{g} / \mathrm{ml}$ 5-FU alone. 

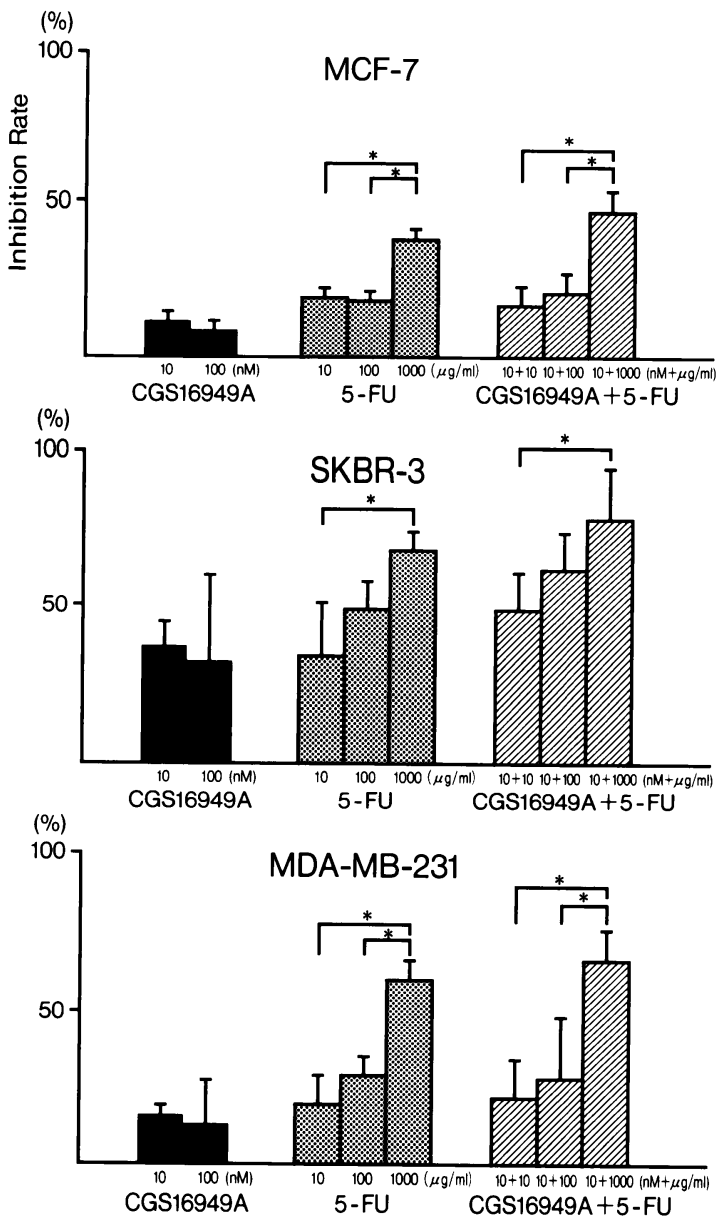

Fig. 2. The effect of aromatase inhibitor CGS16949A and 5-FU, given alone or in combination, on cell proliferation in MCF-7, SK-BR-3, and MDA-MB-231 cell lines as measured with MTT assay. Bars represent mean \pm SD. *Indicates $\mathrm{P}<0.05$, by Fisher's PLSD.

These results suggest addition of CGS16949A and 5-FU might allow doses of 5-FU to be reduced.

In our pilot study, flow cytometry showed that the percentage of cells in the S-phase in each cell line was different. The percentages of cells in S-phase in MCF-7, SK-BR-3, and MDA-MB-231 were $14.02 \%, 21.21 \%$, and $29.05 \%$,respectively. SK-BR-3 and MDA-MB231 showed a higher percentage of S-phase cells than did MCF-7. 5-FU has been shown to act more effectively on cells in S-phase ${ }^{17)}$. The results of the MTT assay suggest a specific relationship between 5-FU and the S-phase. Because CGS16949A is an imidazole derivative of aminoglutethimide, aminoglutethimide affects the G0/G1 fraction of cell nuclei in the MXT mouse mammary tumor in vivo ${ }^{18)}$. In this study, combined treatment with CGS16949A and 5-FU was most effective against SK-BR-3 cells, a finding that suggests that combination therapy might be effective as a postoperative adjuvant therapy against breast cancers that have high aromatase activity and a high percentage of cells in S-phase. 


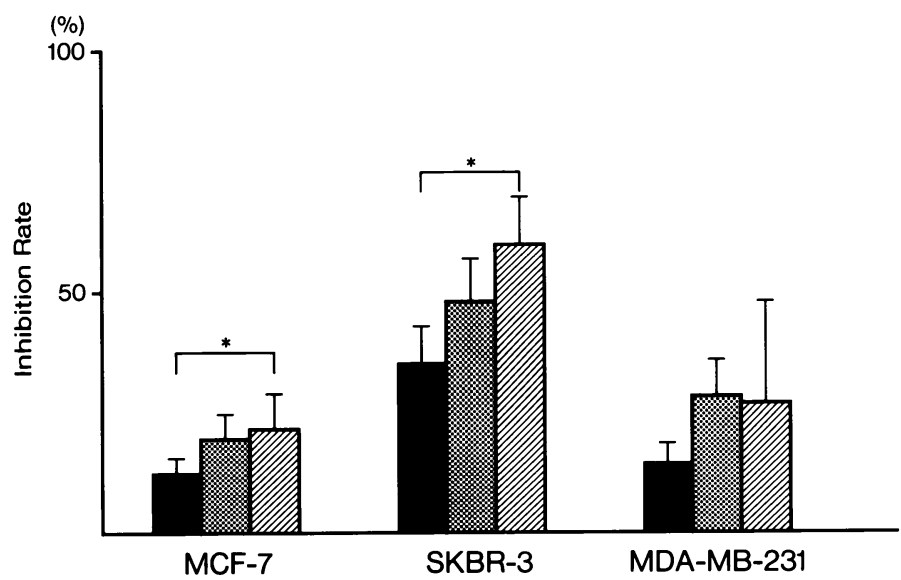

Fig. 3. The effect on cell proliferation of CGS16949A (10 nM) and 5-FU (100 $\mu \mathrm{g} / \mathrm{ml})$, given alone or in combination in MCF-7, SK-BR-3, and MDA-MB231 cell lines, as measured with MTT assay. Bars represent $\mathrm{m}$ ean \pm SD. ${ }^{*}$ Indicates $\mathbf{P}<0.05$, by Fisher's PLSD.

$\square$, Control : $\square$, CGS16949A (10 nM); $\$$, 5-FU $(100 \mu \mathrm{g} / \mathrm{ml})$; and

W/. CGS16949A (10 nM) and 5-FU $(100 \mu \mathrm{g} / \mathrm{ml})$.

Recently, hormonal agents have become the treatment of choice for most postmenopausal patients with advanced breast cancer, and aromatase inhibitors have achieved satifactory therapeutic results when used as a first-line treatment ${ }^{19)}$. The combination of hormonal agents and 5-FU was often used without reference to hormone receptor status as an adjuvant therapy after surgery. In this study, combined treatment with CGS16949A and 5-FU was most effective against the SK-BR-3 cell line, a finding that suggests that combination therapy might be effective as a postoperative adjuvant therapy against breast cancers that have high aromatase activity. Furthermore, the combination may also allow the effective dose and side effects of 5-FU to be reduced.

\section{References}

1) Bezwoda WR, Mansoor $\mathbf{N}$ and Dansey $\mathbf{R}$ : Correlation of breast tumor aromatase activity and response to aromatase inhibition with aminoglutethimide. Oncology $44: 345-349$ (1987)

2) Bezwoda WR, Mansoor N, Dansey R and Esser JD: Aromatisation of androstenedione by human breast cancer tissue: Correlation with hormone receptor activity and possible biologic significance. Oncology 44:30-33 (1987)

3) Santner SJ, Chen S, Zhou D, Korsunsky Z, Martel J and Santen RJ : Effect of androstenedione on growth of untransfected and aromatase-transfected MCF-7 cells in culture. J Steroid Biochem Mol Biol 44:611-616 (1993)

4) Ibrahim NK and Buzdar AU : Aromatase inhibitors : current status. Am J Clin Oncol 18 : 407-417 (1995)

5) Santen RJ, Worgul TJ, Lipton A, Harrey H, Boucher A, Samijlik E and Wells SA : Aminoglutethimide as treatment of postmenpausal women with advanced breast cancer. Ann Intern Med 96 : 94-101 (1982)

6) Harris AL, Powles TJ and Smith IE : Aminoglutethimide in the treatment of advanced postmenopausal breast cancer. Cancer Res 42(Suppl.) : 3405s-3408s (1982)

7) Fukuoka M, Kitawaki J, Yamamoto T and Okada H: Growth inhibition of MCF-7 human breast cancer cells by aromatase inhibitors. Nippon Sanka Fujinka Gakkai Zasshi 43 : 1667-1673 (1991) (in Japanese)

8) Santen RJ, Langecker P, Santner SJ, Slkka S, Rajfer J and Swerdloff R : Potency and specificity of CGS-16949A as an aromatase inhibitor. Endocr Res $16: 77-91$ (1990) 
9) Johnston PG, Drake JC, Trepel J and Allegra JC: Immunological quantitation of thymidylate synthase using the monoclonal antibody TS 106 in 5-fluorouracil-sensitive and-resistant human cancer cell lines. Cancer Res 52 : 4306-4312 (1992)

10) Braakhuis BJM, Visser GWM, Stringer I and Peters GJ : In vitro antiproliferative and metabolic activity of eight novel 5-fluorinated uracil nucleosides. Eur J Cancer 27 : 250-253 (1991)

11) Shimodaira K, Fujikawa H, Okura F, Shimizu Y, Saito H and Yanaihara T: Osteoblast cells (MG-63 and HOS) have aromatase and $5 \partial$-reductase activities. Biochem Mol Biol Int 39 : 109-116 (1996)

12) Kitawaki J, Fukuoka $M$, Yamamoto $T$, Honjo $H$ and Okada $H$ : Contribution of aromatase to the deoxyribonucleic acid synthesis of MCF-7 human breast cancer cells and its suppression by aromatase inhibitors. J Steroid Biochem Mol Biol 42 : 267-277 (1992)

13) Okubo K, Jinbo M, Toma Y, Shimizu Y and Yanaihara T: Aromatase and estrogen 2-hydroxylase activities of human placental microsomes in pregnancy-induced hypertension. Endocr $J 43$ : 363-368 (1996)

14) Yano S, Tanaka $M$ and Nakao K: Anti-tumour effect of aromatase inhibitor, CGS16949A, on human breast cancer cells. Eur J Pharmacol 289 : 217-222 (1995)

15) Dowsett M, Macaulay V, Gledhill J, Ryde C, Nicholls J, Ashworth A, Mckinna JA and Smith IE : Control of aromatase in breast cancer cells and its importance for tumor growth. J Steroid Biochem Mol Biol 44 : 605-609 (1993)

16) Chu E, Drake JC, Koeller DM, Zinn S, Jamis-Dow CA, Yen GC and Allegra CJ : Induction of thymidylate synthase associated with multidrug resistance in human breast and colon cancer cell lines. Mol Pharmacol 39 : 136-143 (1990)

17) Ueki H : Synergistic effect of cell Kinetics-directed chemo-endocrine therapy on experimental mammary tumors. Nippon Geka Gakkai Zasshi 88 : 1576-1583 (1987) (in Japanese)

18) Launoit $Y$ D and Kiss $R$ : In vivo influence of androgens on the cell kinetics and chromatin pattern of the MXT mouse mammary tumor treated or not by aminoglutethimide. J Cancer Res Clin Oncol 115:129-138 (1989)

19) Smith JE, Harris AL, Morgan M, Ford HT, Gazet JC, Harmer CL, White H, Parson CA, Villardo A, Walsh $G$ and Mckin JA: Tamoxifen versus aminoglutethimide in advanced breast carcinoma: a randomised cross-ove1r trial. $\mathrm{Br}$ Med J 283 : 1432-1434 (1981)

[Received December 2, 1997 : Accepted January 8, 1998] 